\title{
Changing Profile of Herpes Zoster in Nepal: A Hospital-Based Study.
}

\author{
Kayastha BMM ${ }^{1}$, Shrestha $\mathrm{P}^{2}$, Shrestha $\mathrm{R}^{2}$, Lama L ${ }^{2}$ \\ ${ }_{2}^{1}$ Associate Professor and Senior Consultant Dermatologist \\ 2 Residents \\ Department of Dermatology and STD \\ National Academy of Medical Sciences (NAMS), \\ Bir Hospital, Kathmandu, Nepal \\ Correspondence: bmkayastha@gmail.com
}

\begin{abstract}
Background: Herpes zoster (HZ), commonly known as shingles, is a localized disease characterized by unilateral radicular pain and a vesicular eruption that is generally limited to the dermatome innervated by a single spinal or cranial sensory ganglion. Although a relatively common cause of morbidity, especially among the elderly, contemporary estimates of HZ in different groups are lacking. Herein we describe a hospital-based study of herpes zoster in a central hospital of Nepal.

Objectives: This study was undertaken to i) Know the age and sex distribution of HZ, ii) Observe the seasonal variation of $\mathrm{HZ}$ and iii) Observe the dermatomal involvement of $\mathrm{HZ}$ patients.

Methods: The study included 174 consecutive patients attending Department of Dermatology and

Sexually Transmitted Diseases (STD), Bir Hospital, National Academy of Medical Sciences (NAMS),

Kathmandu, Nepal and diagnosed with $\mathrm{HZ}$ by dermatologic examination and recorded in the OPD

register within one year were retrospectively analyzed.

Results: there was an overall incidence of 0.66 percent among the new patients with M: F ratio being 2.16:1. The maximum incidence was noted in the second and third decades. A higher incidence was observed in the month of mid April to mid July. Thoracic segments were most commonly $(56.32 \%)$ involved followed by cervical (16.67\%), lumbo-sacral $(14.94 \%)$ and, cranial $(12.07 \%)$ segments. Conclusion: From the present study and the previous published reports from Nepal and India, it is evident that the age profile of herpes zoster patients is quite lower than in the reports published from other regions of the world.

Keywords: Herpes zoster, Clinico-epidemiological profile, dermatomes
\end{abstract}

\section{Introduction}

Herpes zoster (HZ), commonly known as shingles, is a localized disease characterized by unilateral radicular pain and a vesicular eruption that is generally limited to the dermatome innervated by a single spinal or cranial sensory ganglion. The individual lesions are characterized by grouped vesicles on an erythematous base. It occurs as a result of reactivation of varicella zoster virus (VZV) that had persisted in latent form within sensory ganglion following an earlier attack of varicella. ${ }^{1}$ Varicella-Zoster Virus is an exclusively human DNA virus, hence, also known as human (alpha) herpes virus 3, whose primary infection in the human produces chicken pox (varicella). ${ }^{2}$ During varicella infection, VZV passes from skin lesions into cutaneous sensory nerve endings and ascends up the sensory fibers to the sensory ganglia where it remains in latent stage. ${ }^{3}$ In latency, the virus persists in a noninfectious form with intermittent periods of reactivation and shedding. Antigen-specific T cells are believed to be the principal gatekeepers of latent VZV. Conditions in which cellular responses were lost or diminished by immunosuppression pose a risk for reactivation of $\mathrm{VZV}$ and recurrent disease manifestation as herpes zoster. $4,5,6$ The biologic mechanisms that underlie the transition from/atency to active viral replication are unknown. On reactivation, it travels back along the sensory afferents to the skin associated with hematogenous dissemination. Depending upon the rapidity of immune response, the presentation may vary from no clinical lesions, to typical zoster, scattered vesicles, zoster sine herpete or disseminated zoster.

Herpes zoster has traditionally affected persons with more than 60 years of age. ${ }^{9}$ Herpes zoster in older individuals is associated with loss of VZVspecific cellular immunity. 10 Epidemiologic surveys conducted over the last 50 years suggest that the incidence of $\mathrm{HZ}$ in the normal host may be increasing. ${ }^{11}$ The recorded incidence of $\mathrm{HZ}$ has been found to be $64 \%$ higher than that reported 40 years ago. ${ }^{12}$ Herpes zoster occurs throughout the year without seasonal prevalenç, and it affects both sexes and all races equally. ${ }^{13,14}$ Increasing age has clearly been established as the most important risk factor for the development of $\mathrm{HZ}$ .There is a significant increase in the age-specific 
incidence of $\mathrm{HZ}$ beginning at around 50-55 years of age; individuals over 75 years of age have a zoster incidence of over 10 cases per 1000 person years. In a population based investigation on the incidence of HZ by Donahue et al. (1995), the incidence did not vary by gender. Although the rate increased sharply with age, approximately $5 \%$ of the cases occurred among children younger than 15 years. In addition to age, the other welldefined risk factor for $\mathrm{HZ}$ is altered cell mediated immunity (CMI) (Gnann and Whitley 2002). Although herpes zoster is not a reportable disease, an estimated 300000 to 500,000 cases occur annually in the United States.

There are very few hospital-based studies on the epidemiology and clinical profiles of $\mathrm{HZ}$ in South Asia. Although a relatively common cause of morbidity, especially among the elderly, contemporary estimates of $\mathrm{HZ}$ in different groups are lacking. Herein we describe a hospital-based study of herpes zoster in a central hospital of Nepal.

\section{This study was undertaken to:}

1. Know the age and sex distribution of HZ.

2. Observe the seasonal variation of $\mathrm{HZ}$.

3. Observe the dermatomal involvement of $\mathrm{HZ}$ patients.

\section{Materials and methods}

The study included 174 consecutive patients suffering from $\mathrm{HZ}$, who were all out patients and presented to the hospital for the first time at the Department of Dermatology and Sexually Transmitted Diseases (STD), Bir Hospital, National Academy of Medical Sciences (NAMS), Kathmandu, Nepal between Baishakh 2064 B.S. to Chaitra 2064 B.S.(15 ${ }^{\text {th }}$ April 2007 to11th April 2008). All patients diagnosed with $\mathrm{HZ}$ by dermatologic examination and recorded in the OPD register were analyzed.

\section{Results}

One hundred and seventy four cases of $\mathrm{HZ}$ were recorded from $2^{\text {nd }}$ of Baishakh $2064 \mathrm{BS}$ to $29^{\text {th }}$ of Chaitra 2064 BS (i.e. $15^{\text {th }}$ April 2007 AD to 11thApril 2008 AD). A total of 26,489 new cases attended the Dermatology and STD OPD of Bir Hospital during the study period, thus the frequency of occurrence of herpes zoster amongst skin OPD cases was more than 0.65 per cent (approximately 6.57 cases per thousand). Among them 119 $(68.39 \%)$ were males and $55(31.61 \%)$ were females (Table I); the male: female (M: F) ratio being 2.16:1. The minimum and maximum age of the patients was 10 and 81 years respectively. The mean age at presentation was 34.5+/-SD 17.85 years. As evident from the Table I, more than $67.24 \%$ of the patients were below 40 years of age, where as $77.01 \%$ of the patients were below 50 years of age, and only $22.99 \%$ were above 50 years.

Approximately $15 \%$ of the patients attended the hospital in the month of Jestha (Table 2). The disease was more prevalent during the months of Baishakh to Ashad (mid April to mid July) (Fig.1).

Ninety-eight (56.32\%) patients had involvement of thoracic dermatomes and $29(16.67 \%)$ patients had involvement of cervical dermatomes (Table 3 , Figure 2). A total of 26(14.94\%) patients suffered from lumbo-sacral zoster followed by cranial zoster $(12.07 \%)$ (Figure 3 ). There was very significant increase in the number of Herpes zoster ophthalmicus cases in male patients (Table 3).

Table-1. Age and gender distribution of patients.

\begin{tabular}{|c|c|c|c|}
\hline $\begin{array}{l}\text { Age group } \\
\text { (in years) }\end{array}$ & Male (\%) & Female (\%) & Total (\%) \\
\hline $10-19$ & $25(14.37)$ & $10(5.75)$ & $35(20.11)$ \\
\hline $20-29$ & $40(22.99)$ & $17(9.77)$ & $57(32.76)$ \\
\hline $30-39$ & $16(9.19)$ & $9(5.17)$ & $25(14.37)$ \\
\hline $40-49$ & $11(6.32)$ & $6(3.45)$ & $17(9.77)$ \\
\hline $50-59$ & $10(5.75)$ & $3(1.72)$ & $13(7.47)$ \\
\hline $60-69$ & $9(5.17)$ & $9(5.17)$ & $18(10.34)$ \\
\hline $70-79$ & $6(3.45)$ & $1(0.57)$ & $7(4.02)$ \\
\hline Above 80 & $2(1.15)$ & $0(0.00)$ & $2(1.15)$ \\
\hline Total & $119(68.39)$ & $55(31.61)$ & $174(100 \%)$ \\
\hline
\end{tabular}

Table-2. Month wise distribution of the cases of Herpes zoster

\begin{tabular}{|l|r|r|l|}
\hline \multicolumn{1}{|c|}{ Month } & Male & \multicolumn{1}{c|}{ Female } & \multicolumn{1}{c|}{ Total (\%) } \\
\hline Baishakh(mid April-mid May) & 12 & 6 & $18(10.34)$ \\
\hline Jestha (mid May-mid June) & 19 & 7 & $26(14.94)$ \\
\hline Ashad (mid June-mid July) & 16 & 6 & $22(12.64)$ \\
\hline Shrawan (mid July-mid August) & 15 & 4 & $19(10.92)$ \\
\hline Bhadra (mid August-mid Sept) & 8 & 7 & $15(8.62)$ \\
\hline Asoj (mid Sept.-mid Oct) & 7 & 4 & $11(6.32)$ \\
\hline Kartik (mid Oct.-mid Nov.) & 7 & 1 & $8(4.6)$ \\
\hline Mangshir (mid Nov.-mid Dec) & 4 & 5 & $9(5.17)$ \\
\hline Pousha (mid Dec.--mid Jan.) & 4 & 5 & $9(5.17$ \\
\hline Maagh (mid Jan.-mid Feb.) & 1 & 2 & $3(1.72)$ \\
\hline Falgun (mid Feb.-mid March) & 16 & 4 & $20(11.49)$ \\
\hline Chaitra (mid March-mid April) & 10 & 4 & $14(8.05)$ \\
\hline
\end{tabular}

Table-3. Dermatomal involvement according to gender in herpes zoster.

\begin{tabular}{|l|l|l|}
\hline Dermatome involved & Male $(\%)$ & Female $(\%)$ \\
\hline HZ ophthalmicus & $16(9.16)$ & $1(0.57)$ \\
\hline HZ Maxillary & $2(1.15)$ & $1(0.57)$ \\
\hline HZ mandibular & $1(0.57)$ & $0(0.00)$ \\
\hline Cervical & $20(11.49)$ & $9(5.17)$ \\
\hline Thoracic $1-6$ & $34(19.54)$ & $17(9.77)$ \\
\hline Thoracic $7-12$ & $31(17.82)$ & $16(9.2)$ \\
\hline Lumbar & $10(5.75)$ & $5(2.87)$ \\
\hline Sacral & $5(2.87)$ & $6(3.45)$ \\
\hline
\end{tabular}


Figure 1. Line diagram showing trend of herpes zoster through out the year.

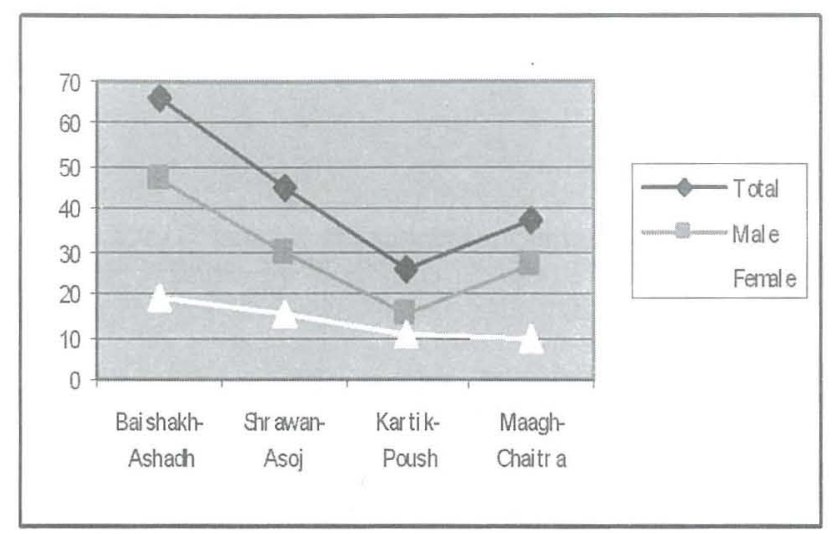

Figure 2. Herpes zoster of C6-7 dermatome.

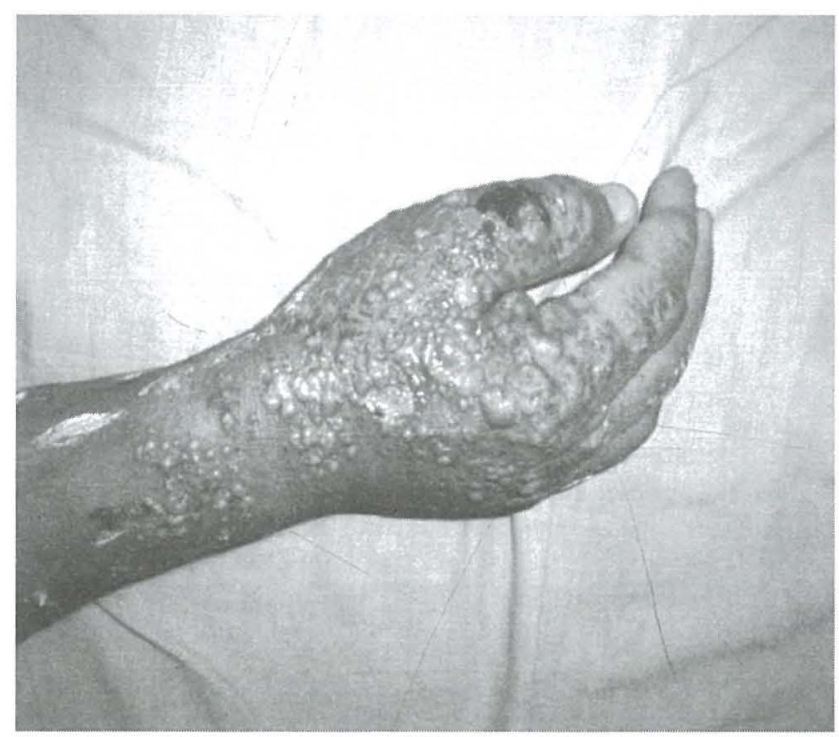

Figure 3. Herpes zoster involving the maxillary division of Trigeminal nerve in a 67 years-old lady(file photo).

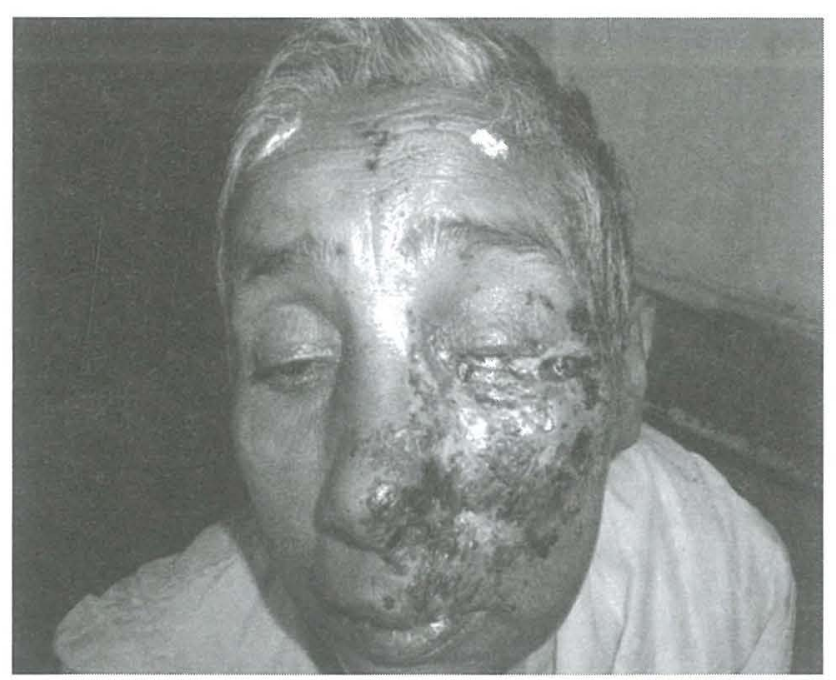

Discussion

A hospital based study of herpes zoster is lacking in our country. Our aim in undertaking this study was to take a first step towards finding the epidemiological parameters in the incidence of
HZ. One can argue that the population studied does not represent the whole country as it is done in urban setting in a highly biased sample. But we think that our sample is fairly representative as because. Bir Hospital is the central governmental and tertiary referral hospital of the country with patients coming to this hospital from all over the country. In a study of 274 cases of HZ, Kayastha and Shilpakar (2005) has revealed an overall incidence of 0.98 percent of $\mathrm{HZ}$ cases among patients attending the Dermatology OPD of Bir Hospital.16 The mean age at presentation was 34.6 years +/- SD 16.7 with the highest number of cases occurring in the 3rd decade $(32.85 \%)$ and the male: female ratio was $2.46: 1$. They had reported that more than $82 \%$ of the patients were below 50 years of age. Our study has shown that the mean age of the HZ patients is $34.5+/$-SD 17.85 years, and the maximum incidence is seen in 2nd and 3 rd decade (20.11\% and $32.76 \%$ respectively). More than 2/3rd of the patient population consisted of males (M: F ratio being 2.16:1) and more than $77 \%$ of the patients were below 50 years of age. According to Dubey et al. (2005) more than two thirds of the cases occur in individuals over fifty years of age and less than ten percent occur in those under the age of twenty years. The average age at presentation in our study is a decade less than the findings of Goh and Khoo.17 Eighty $(74.7 \%)$ of our cases were less than 50 years that is much higher percentage than seen in their study. The maximum incidence of $\mathrm{HZ}$ in second and third decade has been found by Chaudhary et al.,18 and $\mathrm{M}$ : F ratio of 2.2:1 was seen in the same study. In a study by Laxmisha et..al on forty cases of herpes zoster which included 5 children and 35 adults; majority of the cases (75\%) occurred below 50 years of age, $22.5 \%$ of cases were below 20 years. 19 Mullooly et al., in 2005 found significant increase in HZ incidence rates in Oregon and Washington during 1997-2002 among children aged 10-17 years apparently associated with increased exposure to oral steroids.20 But other studies have put the maximum incidence of $\mathrm{HZ}$ in the age group of above 50 years. 21 Our study had $12(4.4 \%)$ patients who were younger than 15 years.

Gershon (1995) has stated that HZ is unusual in young adults; and it occurs with equal frequency through the year. But our study reveals that it is more frequent during the months of mid-April to mid-July. Some seasonal variation of $\mathrm{HZ}$ has been found by Peto TEA and Juel- Jensen BE22 Chaudhary et al. in 1987 found a higher incidence of HZ in the months of March - May and AugustOctober, which was correlated with the increased incidence of varicella during these months by Haribhakti and Macwan(2001).23 
The maximum number of our cases had involvement of thoracic dermatomes (56.32) which was followed by cervical $(16.67 \%)$, cranial $(12.07 \%)$ and lumbosacral $(14.94 \%)$ dermatomes which is similar to the study by Chaudhary et al. and De Biasi RL et al.24 According to De Biasi et al., 14 to $20 \%$ of patients had disease in the distribution of a cranial nerve. In the study of Laxmisha et.al (2004) the dermatomes involved in decreasing frequency were thoracic ( 24 cases i.e. $60 \%$ ), followed by ophthalmic (6 cases i.e. $15 \%$ ) and sacral ( 5 cases i.e. $12.5 \%)$ ). In contrast to the statement by Ragozzino et al., that HZO appears to affect a slightly different population than zoster of the other dermatomes, with elderly males being more at risk, we found the incidence of HZO in the younger population similar to other dermatomes(mean age of 40.94 years).

\section{Conclusion}

Our study supports the report given by Chaudhary et al. (1987) and Laxmisha et al.(2004) that HZ is occurring in younger patients than previously reported in western literatures. Since herpes zoster may occur in HIV-infected persons who are otherwise asymptomatic, serologic testing may be appropriate in patients without apparent risk factors for $\mathrm{HZ}$ (e.g., healthy persons who are younger than 50 years of age (Gnann and Whitley, 1997).

\section{Acknowledgement}

We would like to thank Dr. Rushma Shrestha, Mr. Dilli Ram Acharya, Mrs. Amar Shova Dangol and Ms. Sushupti Kayastha for their secretarial assistance.

\section{References:}

1. Straus SE, Schmader KE, Oxman MN. In: Freedberg IM, Eisen AZ, Wolff K, Austen KF, Goldsmith LA, Katz SI, eds. Fitzpatrick's Dermatology in General Medicine. 6th edn., Vol. 2. New York: McGraw Hill, 2003: 207085.

2. Braunstein BL, Provost TT. Cutaneous Medicine. In: Harvey AM, John RJ, Mc Kusick VA et al.eds. The Principles and Practice of Medicine, Connecticut: Appleton \& Lange; 1988: 1198-1214.

3. Talwar S, Shrivastava VK. Herpes zoster ophthalmicus with total ophthalmoplegia. Indian J Dermatol Venereol Leprol 1991;56:454-5.

4. Guess HA, Broughton DD, Melton LJ III, Kurland LT. Epidemiology of herpes zoster in children and adolescents: a population-based study. Pediatrics. 1985;76:512-517.

5. Baba K, Yabuuchi H, Takahashi M, Ogra PL. Increased incidence of herpes zoster in normal children infected with varicella zoster virus during infancy: communitybased follow-up study. J Pediatr. 1986;108:372-377.

6. Smith CG, Glaser DA. Herpes zoster in childhood: case report and review of the literature. Pediatr Dermatol. 1996;13:226-229.

7. Gilden DH, Kleinschmidt-DeMasters BK, Laguardia JJ, Mahalingam R, Cohrs RJ.Neurologic Complications of the Reactivation of Varicella-Zoster Virus, N Engl J Med 2000; 343:221-223.
8. Talwar S. Herpes zoster associated with varicelliform eruption. Indian J Dermatol Venereol Leprol 1991; 57:52.

9. Dubey AK, Jaisankar TJ, Thappa DM. Clinical and morphological characteristics of herpes zoster in south India. Indian J Dermatol 2005;50:203-207.

10. Berger R, Florent G, Just M. Decrease in the lymphoproliferative response to varicella-zoster virus antigen in the aged. Infect Immun.1981;32:24-27.

11. Gnann JW Jr., Whitley RJ. Neurologic Manifestations of varicella and herpes zoster. In: Scheld WM, Whitley RJ, Durack DT, eds. Infections of the Central Nervous System,2nd ed. Philadelphia,Lippincott-Raven; 1997: 91- 105 .

12. Donahue JG, Choo PW, Manson JE et al., The incidence of herpes zoster. Arch Intern Med 1995; 155: 719-724.

13. Ragozzino MW, Melton LJ III, Kurland LT, et al., Population-based study of herpes zoster and its sequeale. Medicine (Baltimore) 1982; 51: 310-316.

14. Gershon AA. Varicella Zoster virus infection. In: Kelley WN. Textbook of Internal Medicine, 3rd ed. Philadelphia: Lippincott-Raven; 1997:1775-1778.

15. Weller TH. Varicella and herpes zoster: a perspective and overview.J Infect Dis. 1992; 166 (Suppl) : S1-6.

16. Kayastha BMM, Shilpakar R. Clinico- epidemiological profile of Herpes zoster in Nepal: a hospital- based study. Nepal J Dermatol Venereol Leprol 2005; 5 (5):7-14.

17. Goh CL, Khoo L. A retrospective study of the clinical presentation and outcome of herpes zoster in a tertiary dermatology outpatient referral clinic, Int J Dermatol 1997; 36: 667 72.

18. Chaudhary SD, Dashore A, Pahwa US. Clinico epidemiological profile of herpes zoster in North India. J Dermatol Venereol Leprol 1987; 53: 213-216.

19. Laxmisha C, Thappa DM, Jaisanker TJ. The spectrum of varicella zoster virus infection: a hospital based clinic in south India. Indian J Dermatol 2004; 49(1):28 - 31.

20. Mullooly JP, Riedlinger $\mathrm{KC}$, Chun $\mathrm{C}$ et al., Incidence of herpes zoster, 1997-2002. Epidemiol Infect 2005; 133(2): 245-253.

21. Hope-Simpson RE. The nature of herpes zoster: a long- term study and a new hypothesis. Proc R Soc Med 1965; 58: 9-20.

22. Peto TEA, Juel-Jensen BE. Varicella- Zoster virus infection. In: Weatherall DJ, Ledingham JGG, Warrell DA, eds. Oxford Text Book of Medicine, New york: Oxford University Press; 1996: 346-351.

23. Haribhakti PB, Macwan R. Viral skin infections. In: Valia RG, Valia AR, eds. Textbook and atlas of Dermatology, Mumbai: Bhalani Publishing House; 2001:285-322.

24. De Biasi RL, Solbrig MV, Tyler KL. Infections of the Nervous System. B. Viral infections. In: Bradley WG, Daroff RB, Fenichel GM et al., eds. Neurology in Clinical Practice, 4th ed. Butterworth, Heinemann; 2004: 1515-1543. 